\title{
Learning Literation for the Children Victims of Sinabung Mountain Disaster in Siosar Relocations
}

\author{
Laurensia Masri Perangin Angin, Halimatussakdiah \\ Universitas Negeri Medan, Medan, Indonesia \\ e-mail: laurensia_masri82@yahoo.co.id
}

\begin{abstract}
This study aims to improve literacy learning for the victim of Sinabung Mountain in Siosar Relocation. The problem of this study is the low learning outcomes in literacy learning of the children of Elementary School in Siosar Relocation. Literacy learning with Big Books media can improve the excitement and cheerfulness of children in learning activities in school, so that children will forget the trauma of the disaster that they are experiencing. Furthermore, the application of big book media not only emphasizes the ability to read and write for children, but also can develop good attitude and character. This research method is a descriptive qualitative research. The location of this research was conducted in SDN No. 047175 Siosar Brand Sub-district Karo Regency of North Sumatera Province. This location is an area of relocation of Sinabung disaster victims. Data collection techniques are test, observation, and field notes. The research instruments are performance test and observation sheet. The learning outcomes of grade I SDN 047175 Siosar have improved and increase, the average reading ability 75.30 and writing ability 78.25 . It can be proven from the low achievement of child reading and writing indicator $(76,78)$. Thus, it can be concluded that the learning of literacy for Sinabung disaster victims in Siosar Relocation is increases.
\end{abstract}

Keywords: $\quad$ Learning, Literacy, Children, Siosar

\section{INTRODUCTION}

Literacy learning is the ability of children to read and write the beginning. Literacy learning has a very important role, because the ability does not develop by itself, but needs to be taught appropriately. Good literacy learning will help students understand oral, written, or drawing text. As an underlying ability of other abilities, literacy learning in the early grades needs to receive serious attention from the early classroom teachers. This is match with the Law of National Education System year 2003 Article 4, paragraph 5 explicitly states that "Education is conducted by developing a culture of reading, writing and counting for all citizens" (Article 4 of UU-SISDIKNAS, 2003).

The fact that literacy learning that occurs in elementary school children of Sinabung disaster in Siosar relocation, is very apprehensive. The learning outcomes of grade I SDN 047175 Siosar is far from expectations, the average score of reading ability is 55.30 and writing ability is 58.25 . It is known from the low achievement of reading and writing indicators $(\Sigma$ 56.78). This is caused by several factors, they are: 1) the teacher only gives the example of reading by writing on the blackboard which is then read by the teacher while the students are told to imitate it, 2) the teacher is not very careful in guiding the students (teaching strategy are without any variation), 3) the students are not guided to read individually (4) there are still students who do not know the letters, 5) the students have not been able to clearly distinguish letters that look like b, d and p. 6) students are afraid to sound their voice / fear of being wrong so their mouths seem to mumble like people who read the incantation, 7) the atmosphere of studying are less enjoyable for students.

In addition to the above constraints, there are other factors influenced by the disaster of Mount Sinabung, which is also suspected to be the cause of the low learning of literacy in the relocation of Siosar SDN 047175, namely: (1). Child traumatized by disaster, (2). School activities were carried out in makeshift tents (the number of tents were 3, 1 tents filled with 2 classes, so 3 tents had 6 six classes), (3). Limited facilities, facilities and infrastructure (development stage).

The low level of literacy learning as illustrated by the above findings indicates that the school as a center of the development of reading and writing culture, which is obliged to lay the foundations of 
ability, interest and passion for reading and writing, still fails to fulfill its mission. It is said that, because of this failure, children's access to global communications and technology up to university level will remain low and this poses a serious threat to Indonesia's education quality improvement program.

This aspect of vulnerability that actually justifies the need for innovative literacy learning media that can produce meaningful learning for students. One of the learning media that can be used for learning literacy is Big Book. Big Book media is a storybook with special characteristic that is raised, both text and image, and has a simple text pattern. Teachers easily attract students to focus on reading or stories to read.

Recognizing the importance of efforts to solve the problems faced by children victims of disasters sinabung, the researchers chose Big Books learning media in literacy learning activities (the ability to read and write) in relocation siosar. Hopefully, learning literacy with Big Books media can increase the excitement and cheerfulness of children in learning activities in school, so that children forget the trauma of the disaster that has happened. Furthermore, the application of big book media not only emphasizes the ability to read and write for children, but also can develop good attitude and character in them. It is derived from the meaning or message contained in a story written in Big Books.

After understanding the facts in the field, against the constraints faced by SDN No. 047175 Siosar, hence the main study of this research is: an improvement of literacy learning of child victim of sinabung disaster in relocation of Siosar through Big Book media.

This relocation is located in production forest area in Siosar, District of Merek, Karo District, North Sumatera Province. About $17 \mathrm{~km}$ from Kabanjahe city, the capital city of Karo Regency. Construction of houses will be done to relocate residents from the villages of Simacem and Suka Meriah. The houses will be built in type of 36 . The total number of houses planned to be built is 2,053 which is gradually resumed this year. While the number of refugees of Sinabung that will be relocated are 1700 households (KK). Victims are also given 416 hectares of agricultural land to sustain community life in order to re-establish themselves in the socio-economic activity. Unfortunately, the construction of elementary schools has not been implemented, so the learning process are carried out in makeshift tents. The learning activities were carried out in makeshift tents (the number of tents was 3, 1 tents filled with 2 classes, so 3 tents had 6 six classes).

USAID (2014: 42) explains the Big Book is a book that has large sizes, writings, and drawings. Big Book size can vary, such as A3, A4, A5 size, or the size of a newspaper. The size of the Big Book should take into account the legibility of all students in the class. This large book is usually used for low grade children. Inside contains short stories with big posts given colorful pictures. Big Book learning media is suitable for use in the early classes because it has characteristics that appropriate with the needs of students in the early classes. By using Big Book the teacher can choose the content of the story adapted to the theme of learning. In addition, Big Book is very suitable for learning in reading and writing modeling for beginner. Big Books not only emphasize students' reading and writing skills, but can also develop good attitudes and character in themselves. It is derived from the meaning or message contained in a story written in the Big Book.

Big Books is best used for grade I elementary students in early reading lessons. According to Lynch (2008: 1) Big Books are also used for pedagogical reasons. Big Books allow students to learn to read independently. Big Books builds a reading experience for students. Big Books enriches the spoken language of children by reading. Based on the above opinion, reading the beginning using Big Books media can enrich the oral child through reading activities. Big Books are used for early reading and writing lessons. Teachers can point to every word read and students pay attention. Big Books provides a new reading experience to students.

Literacy learning for victims in relocation sioasar by using Big Books, following the steps of Lynch Barbara (2008: 494) and adapted according to circumstances in Siosar, namely: (a) The teacher makes Big Books itself with a simple story that is suitable for (B) the teacher uses poster paper, manila, cardboard and cardboard for the front, (c) the teacher describes the series of stories on paper, by pasting clip art or pieces of images from used magazines. The front can be coated with a patchwork to look like a thick tale book. (D) when Big Books are used for teaching, teachers first show the front cover and make students have high curiosity. Teachers can ask what students are observing on the cover of Big Books. Students then raise their opinion with simple words. Teachers continue to provoke students to increase their curiosity and focus on lessons. Teachers can write 
on the chalkboard student predictions about the story content in Big Books; (e) furthermore, the teacher starts reading the title and author's name to add predictions from the students. It aims to make the classroom look familiar with the open response. Teachers also associate students' knowledge with the title Big Books, (f) teachers begin to read stories aloud and expressively so that students can focus on the story. The teacher also shows a picture illustration of the story so that students know exactly how to describe the story. Students listen without interrupting to the end of the story, $(\mathrm{g})$ the teacher asks how the content of the story he has read is interesting or not. Students start expressing their reactions, (h) the teacher invites students to read together in a classical loud voice. The teacher points to every word read, (i) the teacher tells the students to read the story in groups so that the students really understand the story, (j) the teacher develops the writing skills of the child by instructing the child to rewrite the read story, then what the child is writing Retold the contents of his story in front of the class.

Based on the above theoretical review, it can be proposed research hypothesis as follows: "Application of big book media can improve learning of literacy in child victims of Mount Sinabung disaster in class I SDN 047175 in relocation Siosar".

\section{METHODS}

This research method is descriptive qualitative research. The location of this research was conducted in SDN No. 047175 Siosar Brand Sub-district Karo Regency of North Sumatra Province This location is a relocation area for Sinabung disaster victims, is considered to represent schools located in the outskirts of villages affected by Sinabung disaster. The time of research is conducted in 2017 starting from March to December.

Sources of data in this study are children affected by Sinabung disaster relocated in Siosar, amounting to 36 people, class I-a and I-b. There are 15 students of class I-a and 17 students of class I-b. The data were collected using tests, observations, and field notes.

The collected data is analyzed descriptively qualitative. Calculate the percentage of research data obtained using the formula as follows.

Achieved score X 100\% $=\ldots \%$ Maximal score
Next determine the average value using the following formula.

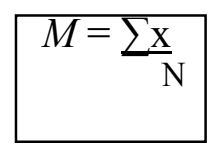

Information :

$\mathrm{M}=$ score average

$\mathrm{N}=$ total of respondent

$\sum \mathrm{x}=$ total score

The success rate is determined by looking at the success criteria that have been set in the table as follows.

Table 1. Success Criteria

\begin{tabular}{ccc}
\hline No & Numbers & Criteria \\
1 & $80-100$ & Very good \\
2 & $66-79$ & God \\
3 & $56-65$ & Enough \\
4 & $40-55$ & Less \\
\hline
\end{tabular}

The success criteria of this research is marked by the improvement to the better, both the learning done in the classroom and the learning atmosphere. Indicator of this research is improvement of learning of literasi both from process and result. The research is said to be successful if it meets the criteria as in the above table that is $75 \%$ of students got value above KKM. The KKM in class I elementary school for the subjects of the Indonesian language is 66 .

\section{RESEARCH RESULT AND DISCUSSION}

\subsection{Research Results}

Based on the data analysis, the following values are obtained. The reading ability of students gets an increase of only 9.6 from the pre test value to 60.8. Observing student learning outcomes is still relatively low and has not fulfilled the predefined criteria of 66 . A total of 18 students $(56 \%)$ have learning outcomes below the completeness standard with the lowest score of 40 . And only 14 people (44\%) complete with the highest score 85 . 
For students 'writing ability, the average score of students' learning achievement is 65.8 with a total of 18 students (56\%) and unfinished 14 (44\%).

Table 2. Recapitulation of Frequency of Learning Literacy

\begin{tabular}{|c|c|c|c|c|c|}
\hline \multirow[b]{2}{*}{ Grade } & \multicolumn{2}{|c|}{ Reading } & \multicolumn{2}{|c|}{ Writing } & \multirow[b]{2}{*}{ Information } \\
\hline & F & $\%$ & F & $\%$ & \\
\hline$)-55$ & 17 & $53 \%$ & 14 & $44 \%$ & [ Not good \\
\hline $6-65$ & 1 & $3 \%$ & 1 & $3 \%$ & L Less \\
\hline 6- 75 & 12 & $38 \%$ & 11 & $34 \%$ & Enough \\
\hline 6- 89 & 2 & $6 \%$ & 5 & $16 \%$ & Good \\
\hline )- 100 & 0 & 0 & 1 & $3 \%$ & Satisfying \\
\hline Total & 2 & $100 \%$ & $: 2$ & $100 \%$ & \\
\hline
\end{tabular}

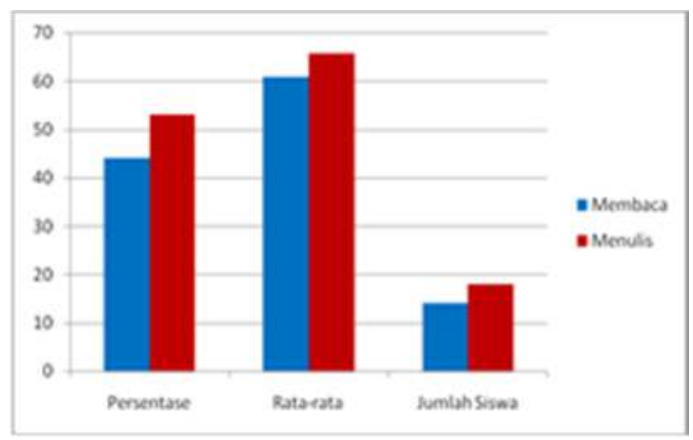

Figure 1. Literacy Learning

From the graph above can know the level of ability with the overall learning formula that is:

1. Reading ability, $P=\frac{14}{32} \times 100 \%=44 \%$ (tuntas )

the average score of 60.8 and the number of students who can afford as many as 14 people. Thus the level of students' ability in reading is still very low.

2. Writing Ability, $P=\frac{17}{32} \times 100 \%=53 \%$ (tuntas)

the average value of 65.8 and the number of students who can afford as many as 17 people. Thus the level of ability of students in writing is still very low. Although there is an increase in the ability to read but has not produced adequate results because it goes to the second cycle.

Based on the results of the implementation and observations made the researchers do a reflection on all activities that result:

1. the percentage level of overall student is still considered low then it needs to be improved

2. researchers have not achieved the desired indicators in the learning process.

3. students who actively express their opinions are still relatively small.
Some students who score below KKM are 18 students $(56 \%)$ for reading ability and 14 students (47\%) for writing ability. This indicates that students still lack the ability to read and write good. Thus the researcher re-do the improvement of learning with the design of alternative solutions to the problem as follows:

1. To know the difficulties of students in reading the beginning of the researcher gives an explanation again how to distinguish letters that are similar like $b, d$ and $p$.

2. Researchers pay attention and help students who have difficulty in reading letters, words and simple sentences.

3. Teachers first explain how to read Big Books.

From the table above we can see the total number of students 26 people $(81 \%)$ and the unfinished 6 people (19\%) with an average value of 75.3 with the difference of increase in average value of 14.5 for reading ability. While the students' ability in writing is still low with the average score of student learning outcomes 75.3 with a total number of complete students as many as 27 people (84\%) and unfinished 5 people (16\%).

Table 3. Recapitulation of Frequency of Literacy Learning Achievement

\begin{tabular}{lccccc}
\hline Jrade & Zeading & \multicolumn{2}{c}{ Writing } & \multicolumn{2}{c}{$\begin{array}{c}\text { Information } \\
\%\end{array}$} \\
$0-55$ & 0 & - & 0 & - & Not good \\
$56-65$ & 6 & $19 \%$ & 5 & $16 \%$ & K Less \\
$56-75$ & 11 & $34 \%$ & 11 & $34 \%$ & Enough \\
$76-89$ & 13 & $41 \%$ & 10 & $31 \%$ & Good \\
$0-100$ & 2 & $6 \%$ & 6 & $19 \%$ & Satisfying \\
Total & 2 & $100 \%$ & 2 & $100 \%$ & \\
\hline
\end{tabular}

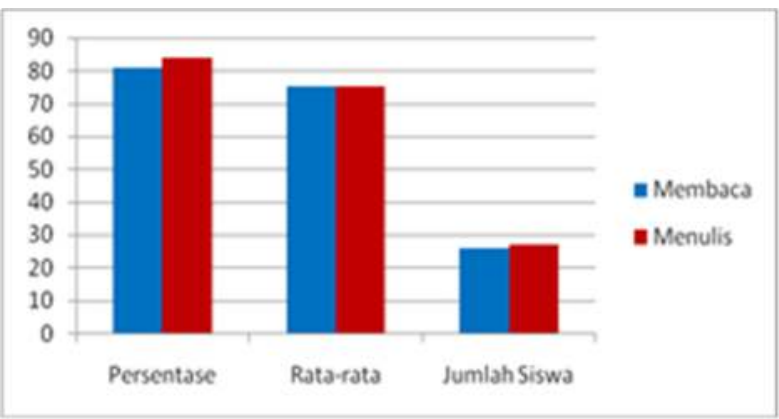

Figure 2. Capability Improvement

From the graph above can know the level of ability with the overall learning formula that is: 1. Reading ability 
$P=\frac{26}{32} \times 100 \%=81 \%$ (tuntas ) the average score of 75.3 and the number of students who can afford as many as 26 people. Thus the level of students' ability in reading is quite good.

2. Writing Ability $P=\frac{27}{32} \times 100 \%=84 \%$ (tuntas) the average value of 75.3 and the number of students who can afford as many as 27 people. Thus the level of ability of students in writing is good. Although the results obtained have not reached $100 \%$, but has been completed in a classical manner that is $81 \%$ for reading ability and $84 \%$ for writing ability. These results have met the criteria of classical completeness of $75 \%$.

From the above number can be seen the percentage of observations as follows:

$P=\frac{53}{60} \times 100 \%=88,3 \%$ of all indicators.

Table 4. Student Observation Results During Learning Activity

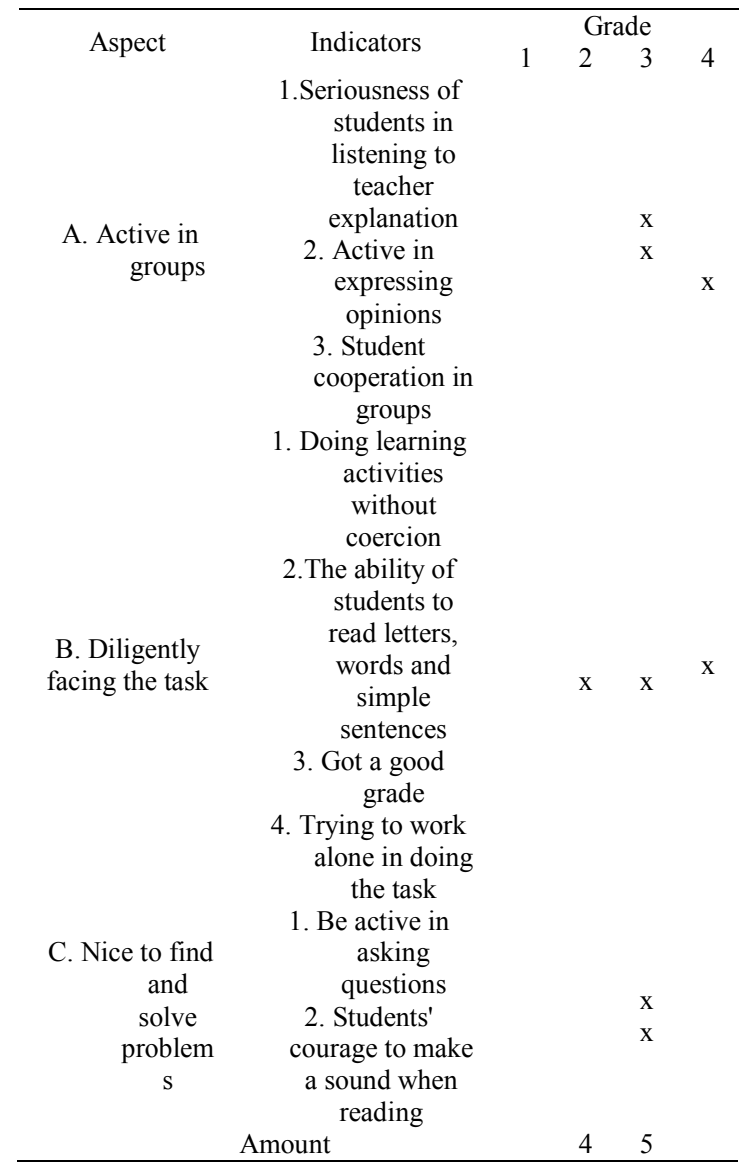

From the table above can be seen the percentage of observations as follows:
$P=\frac{23}{26} \times 100 \%=88,46 \%$ of all indicators.

So the percentage of $88.46 \%$, the observation of student activity at the time of teaching and learning activities can be categorized by good judgment. Thus it can be concluded that during the learning process lasted $88.46 \%$ of student activity has gone well in accordance with the expected.

Based on the results of the implementation and observation obtained increased literacy ability of students. The mean score was 60.8 for reading skills and 65.8 for writing skills, with a percentage of $44 \%$ for reading skills and $53 \%$ for writing skills; in the results of students' ability tests in literacy learning obtained an average score of 75, 3 for reading and writing skills with an $81 \%$ percentage for reading skills and $84 \%$ for writing skills. This shows that literacy learning with the use of Big Books media can improve literacy ability of first grade students SDN 047175 Siosar.

\subsection{Discussion}

Literacy learning with the use of Big Book media can improve the ability to read and write the beginning of the first grade students on Indonesian lessons with the subject reading loud syllables, words, and simple sentences. The result of the research before the action is given, for the reading skill of the average grade grade is 51,3 with the complete student learn as much as 8 students, for the writing skill average grade equal to 59,8 with the complete student learn as much 11.Setelah giving treatment through Learning with the use of big book media grade average grade increased for reading skills to 60.8 with a total number of students who complete learning as many as 14 students and for writing skills to 65.8 with a total number of students who thoroughly learn as many as 18 students. The average grade grade added increased again to 75.3 for reading and writing skills with a complete number of students 26 for reading skills and 27 for writing skills. Based on the result of the average score of students and the percentage of students completeness that has been collected by the researcher can be seen that with the use of big book media can improve literacy ability that is reading and writing the beginning in the first grade students.

Based on the results of data reflection I and data II that have been done by the researcher, then there is a change in the increase of learning outcomes seen during the study. 
Table 5. Completion of Student Learning Results

\begin{tabular}{|c|c|c|c|c|c|}
\hline & \multicolumn{2}{|c|}{$\mathrm{R} \quad$ Average } & \multicolumn{2}{|c|}{ Percentage } & $\mathrm{Ke}$ \\
\hline & $\begin{array}{c}\text { Readin } \\
\mathrm{g}\end{array}$ & $\begin{array}{c}\text { Writi } \\
\text { ng }\end{array}$ & $\begin{array}{c}\text { Readi } \\
\text { ng }\end{array}$ & $\begin{array}{l}\text { Writi } \\
\text { ng }\end{array}$ & $\begin{array}{c}\text { Informat } \\
\text { ion }\end{array}$ \\
\hline Pre test & 51,3 & 59,8 & $25 \%$ & $34 \%$ & Unable \\
\hline Data I & 60,8 & 65,8 & $44 \%$ & $53 \%$ & Unable \\
\hline Data II & 75,3 & 75,3 & $81 \%$ & $84 \%$ & Able \\
\hline
\end{tabular}

Table 6. Research Result

\begin{tabular}{|c|c|c|c|c|c|c|c|}
\hline \multirow[b]{2}{*}{$\begin{array}{l}\mathrm{N} \\
\mathrm{o}\end{array}$} & \multirow[b]{2}{*}{ Research Result } & \multicolumn{3}{|c|}{ Reading Grade } & \multicolumn{3}{|c|}{ Writing Grade } \\
\hline & & Pre test & $\begin{array}{c}\text { Data } \\
\text { I }\end{array}$ & $\begin{array}{l}\text { Data } \\
\text { II }\end{array}$ & Pre test & $\begin{array}{c}\text { Data } \\
\text { I }\end{array}$ & $\begin{array}{c}\text { Data } \\
\text { II }\end{array}$ \\
\hline & Total & 1640 & 1946 & 2410 & 1915 & 2106 & 2410 \\
\hline & Average & 51,3 & 60,8 & 75,3 & 59,8 & 65,8 & 75,3 \\
\hline & $\begin{array}{c}\text { Completene } \\
\text { ss }\end{array}$ & $25 \%$ & $44 \%$ & $81 \%$ & $34 \%$ & $53 \%$ & $84 \%$ \\
\hline
\end{tabular}

The percentage of complete reading of students is ranging from $25 \%$ pre test, $44 \%$ data I and II data $81 \%$. The mean score on pre test 51.3, data I 60.8 and data II 75.3. And the number of students on pre test is 8 , data I 14 and data II 26 students. As for the completeness of writing students ranging from $34 \%$ pre test, data I $53 \%$ and data II $84 \%$. The mean score on pre test 59.8 , data I 65.8 and data II 75.3. And the total number of completed students on pre test is 11 , data I 17 and data II 27 students.

\section{CONCLUSIONS}

In accordance with the results of research that researchers do in SDN 047175 Siosar can be drawn the conclusion that with the use of big book media obtained improvements in student literacy learning that is reading and writing. This can be seen from the level of mastery before and after the research that has been described on the results of research, in addition to the percentage of completeness in classical at the end of data II more than $75 \%$ which means literacy learning is complete.

\section{REFERENCES}

[1] Baynhan, M. 2006. Literacy Practices: Investigation Literacy in Social Context.

[2] United Kingdom: Longman Group Limited.1 995-2.
[3] Colville-Hall, Susan \& Oconnor, Barbara. (2006). Using Big Book: A StandarsBased Instructional Approach for Foreign Language Teacher Candidate in a PreK-12 Program. Foreign Language Annals Vol. 39 Nomor 3. Hlm. 487- 506.

[4] Depdiknas. (2006). Peraturan Menteri Pendidikan Nasional Nomor 22 Tahun 2006 Tentang Standar Isi untuk Satuan Pendidikan Dasar dan Menengah. Jakarta: Depdiknas.

[5] Djiwandono, M Soenardi. 2008. Tes Bahasa Pegangan bagi Pengajar bahasa. Jakarta: PT. Indeks

[6] Farida Rahim. (2005). Pengajaran Membaca di Sekolah Dasar. Jakarta: PT Bumi Aksara.

[7] Iskandarwassid \& Dadang Sunendar. (2009). Strategi Pembelajaran Bahasa. Bandung: PT Remaja Rosdakarya.

[8] Ismawati, Esti \& Umaya, Faraz. 2012. Belajar Bahasa di Kelas Awal. Yogyakarta: Penerbit Ombak.

[9] Kasihani K.E. Suyanto. (2007). English for Young Leraners. Jakarta: PT Bumi Aksara.

[10] Lynch. (2008). A Guide For Using Big Books In The Classrom. Jurnal Scholastic Canada

[11] Mulyana Sumantri, dkk. (2001). Strategi Belajar Mengajar. Bandung: CV Maulana.

[12] Nambiar, Mohana. (1993). Early Reading Instruction-Big Books in the ESL Classroom. Jurnal The English Teacher (Vol XXII). Hlm. 1-7. Nana Sudjana

[13] Sabarti Akhadiah, dkk. (1992/ 1993). Bahasa Indonesia 1. Jakarta: Depdikbud. Sugiyono. (2009). Metode Penelitian Kuantitatif dan Kualitatif. Bandung: Alfabeta.

[14] Sunarto dan Agung Hartono. (2002). Perkembangan Peserta Didik. Jakarta: PT Rineka Cipta.

[15] Stenfri.2015."Relokasi Permukiman Desa Suka Meriah Akibat Kejadian Erupsi Gunungapi Sinabung Kabupaten Karo”. Skripsi. Fakultas Geografi Universitas Gadjah Mada. Yogyakarta.

[16] USAID. 2014. Pembelajaran Literasi Kelas Awal di LPTK. Jakarta: USAID Zuchdi, Darmiyati dan Budiasih. 2001. Pendidikan Bahasa dan Sastra Indonesia di Kelas Rendah. Yogyakarta: PA. 